Pavuk 0.

\title{
PARADOXES IN THE LABOR MARKET OF THE 215T CENTURY: ANALYSIS OF THE MICROBUSINESS IN LATVIA
}

Показано, що віртуалізащія не тільки змінила структуру економіки в бік сфери послуг, а й витісняє зі сфери виробництва найманих пращівників, змушених переходити в розряд дрібних підприємців. Проведено порівняння підприємств і підприємців в Латвії. Доведено, що основну мету будь-якого підприємництва - отримання прибутку - мікропідприємства не досягають, але забезпечують робочі місия і існування своїх сімей.

Ключові слова: віртуалізація економіки, ринок пращі, малий бізнес, мікропідприємства Латвї.

\section{Introduction}

Today much is said about global changes in the labor market. The number of people employed in the world economy is divided almost half-way between wage earners and people of free labor, and there is a tendency to reduce wage labor, which was the driving force of the economy throughout the 20th century. The virtualization of the economy [1], the penetration of modern achievements of the technological revolution in all spheres of human activity not only changed the structure of the economy towards services, but also displaces wage workers. Therefore, it is relevant to study the business environment and microbusiness, which is one of the driving forces of economic development.

\section{The object of research and its technological audit}

The object of research is the indicators of the activities of small and microenterprises in Latvia. Microenterprises as a separate status of entrepreneurial activity appeared at the end of 2010 , as a measure to combat unemployment, sharply increased in the wake of the crisis. As a result, former employees began to open microenterprises, thereby dramatically increasing the number of enterprises in the country and the issue of employment in the labor market was resolved. However, the question of the profitability and collection of taxes remained open on the smallest microenterprises. Lawmakers are introducing stricter measures against the microbusiness, forcing entrepreneurs to close their firms, which will inevitably lead to an increase in unemployment.

One of the most problematic places is the contradiction that arises in the creation of microbusinesses. Many small entrepreneurs, in the recent past hired workers, do not aim to profit and develop the business, but work only to provide for themselves and their families.

\section{The aim and objectives of research}

The aim of the research is identification of the dependence of small and microbusiness and abilities on entrepreneurship on the example of microenterprises in Latvia.
To achieve this aim it is necessary to accomplish the following tasks:

1. To identify employment dependence on microenterprises and reduce unemployment in the country.

2. To show the role of microbusiness in the Latvian economy

3. By analyzing statistical data, to calculate the proportion of people engaged in entrepreneurial activity in relation to the active population.

\section{Research of existing solutions of the problem}

In the economic theory of the 20th century, ideas of the dominant role in the economy of large enterprises prevailed for more than 70 years [2-4]. The economists argue that the dominant role of large enterprises in ensuring economic growth is sound. At the end of the 20th century, small business in various forms, in fact, has become the main driving force for economic and social development of most countries in the world. Even the term «entrepreneurial economy» appeared, based not so much on traditional factors of production (capital and labor), as much on intangible but very important factors as entrepreneurial abilities, organizational talent of doing business [5, 6]. A significant contribution to the theoretical and practical substantiation of the role of entrepreneurship in providing economic growth in the framework of new theories of industrial evolution was made by scientists who assumed that entrepreneurship stimulates and generates economic growth [7-12]. The «cycle of economic life» continues, in which the economy never reaches equilibrium, but with necessity passes from one disequilibrium state to another. The entrepreneur in this circuit is the driving force in the mechanism of changes that have arisen in connection with the virtualization of the economy.

Many authors talk about the virtualization of the economy [13-16]. The penetration of modern achievements of the technological revolution into all spheres of human activity not only changed the structure of the economy towards the services sector [17], but also displaces wage workers forced to become entrepreneurs. In this connection, the question arises: how many people are basically ready to become entrepreneurs. After all, until now it was considered, and any textbook on microeconomics says that $6-8 \%$ of the population has such abilities in the world. 
On an example of Latvia, let's show, what role of businessmen in the country, taking into account active development of microbusiness.

\section{Methods of research}

To achieve this aim, the methods of analysis and synthesis, logical generalization of approaches to the issue of the role of small and microbusiness, comparative comparison of the performance of various forms of entrepreneurial activity in Latvia were used.

\section{Research results}

The crisis of 2008-2009 shows that Latvia's economy is recovering at a faster pace than unemployment is falling. To solve this problem in Latvia, in 2010 a law on microenterprises was adopted, as a result of which many unemployed began to open their enterprises, moving from a camp of former employees to a free enterprise zone.

To demonstrate the role of microbusiness in the Latvian economy, it is worth recalling the history of the issue. The status of microenterprises at the legislative level of a limited liability company was acquired at the end of 2010. The goal of the innovation was noble - to reduce post-crisis unemployment, bringing to the market people who are sitting on benefits. And this goal was achieved. For three years, from 2011 to 2013, the number of jobs in the national economy of Latvia increased by 53 thousand people, and the number of unemployed decreased by 41 thousand. That is, the creation of microenterprises can be considered one of the main factors in reducing the number of unemployed people [18].

Due to the introduction of the status of microenterprise and the introduction of a single turnover tax of $9 \%$ for some of them, the number of such enterprises has increased dramatically. If in 2010 the indicator of economically active merchants and commercial companies per 1000 population was 17, then in 2012 - 74. In 2012, microenterprises accounted for $85.5 \%$ of the total number of commercial companies (Fig. 1).

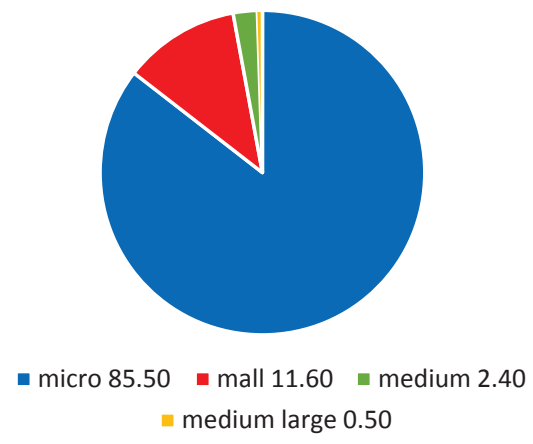

Fig. 1. The share of micro, small, medium and large enterprises in Latvia in 2012, \% [18]

In 2015, out of 123 thousand enterprises operating in Latvia, the Ministry of Finance counted 50,000 microenterprises. True, their combined turnover of 327.3 million EUR was less than $1 \%$ of the turnover of all Latvian companies and is comparable to the turnover of an enterprise such as LDz Cargo (Riga, Latvia) 332.7 million EUR [19]. In subsequent years, the total turnover of all small en- terprises (including micro) was at the level of 23 billion EUR, and the turnover of microenterprises in 2016 was 13.86 billion EUR [20].

The number of employees in micro and small enterprises grew until 2014, after which it decreased slightly (Table 1). In 2016, 468.6 thousand people were employed (in $2012-$ 453.8 thousand), in other enterprises - 238.3 thousand (in 2012 - 217.5 thousand). The decrease in the number is due to the reduction in the number of microenterprises, changes in the regulation of their activities, as well as with digitalization and increased efficiency. It should be noted that $60 \%$ of enterprises in the small business sector employ up to 5 employees. In total, according to Lursoft, in 2016, micro-enterprises employed about 248.57 thousand people or more than a third $(35.2 \%)$ of workers in all Latvian enterprises [20].

Table 1

Number of employees in small and microenterprises of Latvia, thousand people*

\begin{tabular}{|c|c|c|}
\hline Years & 5mall and microenterprises & Other enterprises \\
\hline 2012 & 453.8 & 217.5 \\
\hline 2013 & 470.8 & 229.7 \\
\hline 2014 & 471.2 & 232.1 \\
\hline 2015 & 468.7 & 236.0 \\
\hline 2016 & 468,6 & 238.3 \\
\hline
\end{tabular}

Note: ${ }^{*}$ is compiled on the basis of data [20].

The most noticeable growth of microenterprises was noted in 2010-2011, immediately after the adoption in late 2010 of a new law regulating their activities (Table 2). This can be seen by analyzing the statistics of limited liability companies (LLCs) (microenterprises are created in this form of commercial companies). The share of limited liability companies in 2016-2017 amounted to 59-61\% of all newly registered enterprises [21].

Table 2

Number of active limited liability companies (LLCs) established in Latvia, 2009-2016*

\begin{tabular}{|c|c|c|}
\hline Years & Amount of created active LLC & Number of all active enterprises \\
\hline 2016 & 9952 & 11206 \\
\hline 2015 & 11767 & 13484 \\
\hline 2014 & 12496 & 14965 \\
\hline 2013 & 12844 & 16365 \\
\hline 2012 & 12711 & 16891 \\
\hline 2011 & 13001 & 18045 \\
\hline 2010 & 9768 & 13422 \\
\hline 2009 & 5153 & 9228 \\
\hline
\end{tabular}

Note: ${ }^{*}$ is compiled on the basis of data [21].

The data of Table 2 demonstrate the decline in the creation of limited liability companies in 2016, on the eve of the introduction of measures to restrict the activities of microenterprises. First of all, the reduction was caused by the information about the increase in the turnover tax rate from 9 to $15 \%$ for a part of microenterprises, which turnover is expressed in the smallest figures to 40 thousand EUR per year. In this connection, at the 
end of 2016 - beginning of 2017, microenterprises began to actively get rid of their status or even stop their activities altogether.

Turnovers of small and microenterprises account for $44 \%$ of the aggregate turnover of all enterprises operating in Latvia and, on the whole, maintain their indicators at the same level over the past several years (Table 3 ). It should be added that in the past four years, small business turnover has been within 23 billion EUR, with a slight decline in 2015 and 2016. At the same time, the turnover of microenterprises in 2016 amounted to 13.60 billion EUR [20].

Tahle 3

Dynamics of turnover of small and microenterprises in Latvia, billion EUR*

\begin{tabular}{|c|c|c|}
\hline Years & 5mall and microenterprises & Other enterprises \\
\hline 2016 & 23.14 & 29.45 \\
\hline 2015 & 23.32 & 28.51 \\
\hline 2014 & 23.92 & 29.23 \\
\hline 2013 & 23.58 & 28.93 \\
\hline 2012 & 22.81 & 28.43 \\
\hline
\end{tabular}

Note: ${ }^{*}$ is compiled on the basis of data [22].

The profit of small and microenterprises in 2016 amounted to 702.94 million EUR or a third of the total profits of all enterprises, but still did not reach the level of 2014 (Table 4). Nevertheless, with some decrease in turnover, the aggregate profit of small business in 2016 compared to 2015 increased by $26 \%$, amounting to 702.94 million EUR, of which 404.57 million EUR were earned by microenterprises [20, 22].

Table 4

Dynamics of profit of small and microenterprises in Latvia, million EUR

\begin{tabular}{|c|c|c|}
\hline Years & Small and microenterprises & Other enterprises \\
\hline 2016 & 702.94 & 1617.06 \\
\hline 2015 & 556.58 & 1816.60 \\
\hline 2014 & 866.98 & 1726.42 \\
\hline 2013 & 445.68 & 1248.42 \\
\hline 2012 & 75.07 & 997.78 \\
\hline
\end{tabular}

Note: ${ }^{*}$ is compiled on the basis of data [20, 22].

According to the State Revenue Service of Latvia and Lursoft calculations, small and microenterprises contributed 2.4 billion EUR to the state budget in 2016, or $39 \%$ of all tax payments from Latvian enterprises ( $+4.3 \%$ by 2015$)$. It should be recognized that microenterprises are not those who make a significant contribution to the country's budget, which is troubling the fiscal authorities. But, although in the state treasury of microenterprises in 2016 were added only 46.8 million EUR, this is $8.4 \%$ more than a year earlier $[19,20]$. That is, there is a positive trend and their fiscal function.

But most importantly, the fact that microenterprises provide employment and livelihoods of small entrepreneurs and their families. In many places, especially in the regions, this group of enterprises actually performs a social function. For example, including family members in economic activities and providing them with the necessary means of subsistence, which does not create an additional burden on the social budgets of local authorities. Undoubtedly, this is a positive function of small business.

However, several years of work of microenterprises show that the main goal of any business - profit - microenterprise does not reach. The available data on profits and losses of small and microenterprises show a decrease in their total profit by 20-35\% compared to the most profitable year of 2014 (Table 4).

And here there is a need to consider a question that for many years seemed unshakable. How many participants in the economic process can in principle be entrepreneurs or traders? And is the receipt of profit the only and main goal of any entrepreneur?

It is shown that hired workers are increasingly becoming unclaimed in the real economy, and many of them are involuntarily moving to a new state of their own, becoming individual entrepreneurs or creating small firms that have received the status of microenterprises in Latvia. In fact, these are businessmen, a new bourgeoisie. And really, most of them are people who have lost their job for hire and provide themselves with jobs and the existence of their families. This is evidenced by the figures and facts of the activities of microenterprises that have bred in Latvia several years ago. The purpose of their creation was noble - to reduce the detachment of the unemployed, sharply increased in the crisis 2008-2009. And this goal was achieved. Statistics of their activity over the past few years show that the absolute majority of microenterprises work by zero or is loss-making. That is, the main goal of the capitalist - profit-making - they have not yet achieved. And many, perhaps, did not set such task. No wonder many of the small entrepreneurs call their activities «an organization for themselves a workplace», and even «work for food».

According to the state statistics, at least 177.8 thousand people in Latvia are engaged in business, which follows from the data on economically active enterprises. This group includes self-employed persons, peasant and fishing farms, individual merchants and the largest in number commercial companies (Table 5).

Table 5

Economically active enterprises by type of activity in Latvia *

\begin{tabular}{|l|c|c|}
\hline \multicolumn{1}{|c|}{ Type of business activity } & 2015 & 2016 \\
\hline Self-employed persons & 59578 & 64708 \\
\hline Peasant and fishing farms & 1002 & 10380 \\
\hline Individual merchants & 7331 & 7221 \\
\hline Commercial companies (market sector) & 93824 & 95518 \\
\hline TOTAL & 170735 & 177827 \\
\hline
\end{tabular}

Note: ${ }^{*}$ is compiled on the basis of data [20, 22].

The number of people employed in the national economy in 2016 amounted to 893.3 thousand people. Entrepreneurial structures numbered 177.8 thousand units. (Table 6) To simplify the problem, we will assume that there is only one owner in each enterprise (in fact, there may be more than them, and strictly speaking, managers of the order of the owners do not own the property). Even with this simplification, the number of people engaged in 
business in Latvia will already be about $20 \%$ of the ablebodied population. In turn, according to Lursoft, $99 \%$ or about 121 thousand enterprises in Latvia are small and medium-sized. Of these, $90 \%$ or 109 thousand are microenterprises (including those who work in a facilitated tax regime), where at least one businessman is registered [21].

Table 6

Indicators of employment in Latvia in 2010-2017*

\begin{tabular}{|l|c|c|c|c|}
\hline \multicolumn{1}{|c|}{ Indicators } & 2017 & 2016 & 2015 & 2010 \\
\hline Population, total, thousand people & 1950 & 1966 & 1986 & 2120 \\
\hline $\begin{array}{l}\text { Employed in the national economy } \\
\text { (15-74 years), thousand people }\end{array}$ & 903.0 & 893.3 & 896.1 & 850.7 \\
\hline Number of entrepreneurs, people & No data & 177827 & 170735 & No data \\
\hline $\begin{array}{l}\text { Number of unemployed, thousand } \\
\text { people }\end{array}$ & $84.1^{* *}$ & 95.3 & 98.2 & 205.8 \\
\hline \begin{tabular}{l} 
Unemployment rate, \% \\
\hline
\end{tabular} & 8.2 & 9.6 & 9.9 & 19.5 \\
\hline
\end{tabular}

Note: ${ }^{*}$ is compiled on the basis of data [21, 22].

** Data for the $3 r$ d quarter.

Calculations are approximate. In fact, the proportion of entrepreneurs to the total active population is more than $20 \%$, which destroys the theoretical guidelines of any textbook on macroeconomics, according to which 6-8\% of the active population is able to engage in business.

\section{SWOT analysis of research results}

Strengths. Strongly, it can certainly be considered that microenterprises in Latvia provide employment and livelihoods for new entrepreneurs and their families. Strengths include legislation that simplifies the procedure for opening and reporting microenterprises in Latvia, which has reduced the unemployment rate in the country more than twice as compared to the 2010 crisis. Undoubtedly, the strong side is the involvement of an increasing number of active people in free labor, reducing the burden on the social budget with regard to the payment of unemployment benefits. After the adoption of the Law on MicroEnterprises in 2010, the number of limited liability companies increased by 2.5 times.

Weaknesses. Weaknesses can be considered constant changes in the legislation regulating the activity of microenterprises, including an increase in the rate of turnover tax from 9 to $15 \%$. This creates conditions for the closure of a part of microenterprises or the departure of their owners to the informal sector. Taking into account that in Latvia every fifth inhabitant is subject to the risk of poverty (in $2015-21.8 \%$ of the population), a reduction in the incomes of families that have lost a microbusiness can lead to the growth of the poor.

Opportunities. Opportunities for the development of entrepreneurial activities in the most extensive sector of the economy - small and microbusiness - can be linked with the stabilization of the Law on MicroEnterprises for longer periods.

Threats. Tougher fiscal measures on small businesses in Latvia can lead to the opposite effect - reducing the turnover of microenterprises, leaving some of them in the shade, and thereby reducing tax collection and increasing poverty.

\section{Conclusions}

1. The dependence of employment on microenterprises and reduction of unemployment in the country is revealed. After the introduction of the status of microenterprises in Latvia in 2010, from 2011 to 2013, the number of jobs in the national economy is increased by 53 thousand people, and the number of unemployed is decreased by 41 thousand. That is, the creation of microenterprises can be considered one of the main factors in the reduction of the number unemployed. However, a tightening of fiscal measures in relation to the microbusiness leads to a reduction in microenterprises. The number of limited liability companies (namely, they can get the status of microenterprise) after a few years of growth began to decrease. In 2016, the reduction was almost 2 thousand.

2. The role of microbusiness in the Latvian economy is shown. In 2016, microenterprises employed about 248.57 thousand people or more than a third (35.2\%) of employees of all Latvian enterprises. Turnovers of small and micro enterprises account for $45 \%$ of the total turnover of all operating enterprises and remain at the same level for the last several years. Small and microenterprises contributed 2.4 billion EUR to the state budget in 2016, or $39 \%$ of all tax payments from Latvian enterprises ( $+4.3 \%$ by 2015).

3. By analyzing the statistical data it is calculated that the proportion of persons engaged in business in different types of activity is at least $20 \%$ of the active working population. Thus, a new paradigm is revealed, which overturns the postulate that no more than $6-8 \%$ of the population are able to engage in business. This fact must be taken into account by the state, understanding with regard to small entrepreneurs, without increasing fiscal oppression, but by creating conditions for their development. This fits into a new approach to small business and its role in the development of the national economy. Tightening measures against the microbusiness will cause the opposite effect - reducing turnover and leaving a part of microenterprises in the shadow, which will lead to lower taxes and increased poverty.

\section{References}

1. Pavuk O. Virtual'naya ekonomika: innovativnaya i spekulyativnaya // Problemy transformatsii sovremennoy rossiyskoy ekonomiki: teoriya i praktika organizatsii i obespecheniya upravleniya: proceedings. Moscow: INION RAN, 2011. P. 76-81.

2. Coase R. H. The Nature of the Firm // Economica. 1937. Vol. 4 No. 16. P. 386-405. doi:10.1111/j.1468-0335.1937.tb00002.x

3. Solow R. M. A Contribution to the Theory of Economic Growth // The Quarterly Journal of Economics. 1956. Vol. 70, No. 1. P. 65-94. doi: $10.2307 / 1884513$

4. Chandler A. Scale and scope: The dynamics of industrial capitalism. Cambridge: Harvard University Press, 1990. 780 p.

5. Schumpeter J. A. Essays of J. A. Schumpeter (1951) / ed by Clemence R. V. Kessinger Publishing LLC, 2010. 338 p.

6. Schumpeter J. A. The Instability of Capitalism // The Economic Journal. 1928. Vol. 38, No. 151. P. 361-386. doi:10.2307/2224315

7. Audretsch D. B. Innovation and Industry Evolution. Cambridge: MIT Press, 1995. $280 \mathrm{p}$

8. Ericson R., Pakes A. Markov-Perfect Industry Dynamics: A Framework for Empirical Work // The Review of Economic Studies. 1995. Vol. 62, No. 1. P. 53-82. doi:10.2307/2297841

9. Hopenhayn H. A. Entry, Exit, and firm Dynamics in Long Run Equilibrium // Econometrica. 1992. Vol. 60, No. 5. P. 1127-1150. doi: $10.2307 / 2951541$

10. Jovanovic B. New Technology and the Small Firm // Small Business Economics. 2001. Vol. 16, No. 1. P. 53-56. doi:10.1023/ a:1011132809150 
11. Steven K. Entry, Exit, Growth, and Innovation over the Product Life Cycle // American Economic Review. 1996. Vol. 86, No. 3. P. $562-583$.

12. Schumpeter J. A. The Theory of Economic Development. Cambridge: Harvard University Press, 1934. 255 p.

13. Toffler A. The third wave. New York: Collins, 1980. 544 p.

14. Kovalev D. A. Postindustrial'noe obshhestvo i virtualizatsiya ekonomiki v razvitykh stranakh i Rossii // Problemy sovremennoy ekonomiki. 2004. No. 4 (12). P. 59-61

15. Mantatova L. V. Strategiya razvitiya: Tsennosti novoy tsivilizatsii. Ulan-Ude: Izdatel'stvo VSGTU, 2004. 242 p.

16. Ivanov D. V. Postindustrializm i virtualizatsiya ekonomiki // Zhurnal sotsiologii i sotsial'noy antropologii. 1998. Vol. 1 No. 1. P. 81-90. URL: http://www.jourssa.ru/sites/all/files/ volumes/1998_1/Ivanov_1998_1.pdf

17. Pavuk O., Moldenhauer N. Employment as an indicator of economy virtualisation (by the example of the United States) // Economic Annals-XXI. 2013. Vol. 11-12 (1). P. 23-26.

18. Pavuk O. Research of microenterprises in Latvia in the context of resolving unemployment // Technology Audit and Production Reserves. 2014. Vol. 4, No. 2 (18). P. 32-36. doi:10.15587/23128372.2014.26314

19. Pavuk O. Pirrova pobeda latviyskikh mikropredpriyatiy // Baltic-course.com. Riga, December 15, 2016. URL: http://www. baltic-course.com/rus/kolonka redaktora/?doc $=17443$

20. Mazais bizness nodarbina $66 \%$ no visiem Latvijas uznēmumos strādājošajiem cilvēkiem // Lursoft. Riga, November 15, 2017.
URL: http://blog.lursoft.lv/2017/11/15/mazais-bizness-nodarbina-66-no-visiem-latvijas-uznemumos-stradajosajiem-cilvekiem/

21. Uzṇēmumu registra un komercregistra subjektu reǵistrācijas dinamika sadalījumā pēc to uzn̄ēmējdarbības formas // Lursoft statistika. URL: https://www.lursoft.lv/lursoft statistika/?\&id=15

22. Latvija. Galvenie statistikas rādītāji 2017 // Latvijas statistika. 2017. URL: http://www.csb.gov.lv/sites/default/files/nr_03_latvija_galvenie_statistikas_raditaji_2017_17_00_lv.pdf

\section{ПАРАДОКСЫ НА РЫНКЕ ТРУДА 21 ВЕКА: АНАЛИЗ ДЕЯТЕЛЬНОСТИ МИКРОБИЗНЕСА В ЛАТВИК}

Показано, что виртуализация не только изменила структуру экономики в сторону сферы услуг, но и вытесняет из сферы производства наемных работников, вынужденных переходить в разряд мелких предпринимателей. Проведено сравнение предприятий и предпринимателей в Латвии. Доказано, что основной цели любого предпринимательства - получения прибыли - микропредприятия не достигают, но обеспечивают рабочие места и существование своих семей.

ключевъе слова: виртуализация экономики, рынок труда, малый бизнес, микропредприятия Латвии.

Pavuk Olga, Doctor of Economic Sciences, Associate Professor Baltic International Academy, Riga, Latvia, ORCID: http://orcid. org/0000-0003-3930-7010, e-mail: olga.pavuk@outlook.com

\section{Savchuk $\mathbf{n}$. COMMUNITY ANAIYSIS AS SOCIO- ECONOMIC SYSTEM: SPACE-TERRITORIAL NATURE, FUNCTIONS AND FEATURES}

Проведено аналіз соціально-економічної системи громади. Визначено основні напрямки реформи децентралізації, схематично розглянуто етапи формування громад, виокремлено основні функції територіальних громад, роз'яснено законодавчу частину об'єднання громад. Проаналізовано зарубіжний досвід щодо утворення територіальних громад. Авторами надано власне визначення громади як сочіально-економічної системи.

Ключові слова: територіальна громада, сочіальний розвиток, ресурсне забезпечення, організачійне забезпечення, адміністративно-територіальна реформа.

\section{Introduction}

The reform of local self-government concerns many spheres in the government of the state. That is why a clear understanding of society as a socio-economic system is an important theoretical and methodological basis. Decentralization means the transfer of significant powers and budgets from state bodies to local self-government bodies, as a result of which more authorities had those bodies that are closer to people where such powers can be successfully implemented.

One of the most difficult and urgent tasks on the way of democratization of the socio-political life of Ukraine is the reform of the system of local self-government. The connection between democracy and local self-government is obvious. Democracy is impossible without local government, as the researchers of this problem unanimously point out [1]. The system of local self-government is one of the most important elements and indicators of the democratization of society [2]. It is difficult not to agree with the statement that the key feature of democracy is the existence in the state of an effective model of local self-government [3]. The need to search for an effective model of local self-government makes us turn to conceptual schemes for determining the essence of the phenomenon under investigation, the basic concept of which is the territorial community.

\section{The object of research and its technological audit}

The object of research is society as a socio-economic system, its spatial-territorial nature, functions and characteristics.

Despite differences in understanding of the essence of local government, almost all scientists agree that the 